\title{
Biochemical Study of Serum Zinc in Patients of Breast Carcinoma in Bikaner District
}

\author{
Chawla Kim ${ }^{1}$, Gora Meenakshy², Jaipal Hanuman Prasad ${ }^{3}$, Vyas RK $^{4}$ \\ ${ }^{1}$ M.Sc.(Medicine) Biochemistry, Sr. Demonstrator, Department of Biochemistry, S.P. Medical College, Bikaner (Raj), India \\ ${ }^{2}$ M.D. Biochemistry, Asst. Prof. Department of Biochemistry, S.P. Medical College, Bikaner (Raj), India \\ ${ }^{3}$ Assistant Professor, Department of Medicine, P.B.M. Hospital. Bikaner (Raj), India
}

${ }^{4}$ P.hD (Medicine) Biochemistry, Sr. Prof and Head, Department of Biochemistry, S.P. Medical College .Bikaner (Raj), India

\begin{abstract}
Breast cancer is the second commonest form of cancer among women. Several studies have been conducted to identify potential risk factors. The association of serum trace elements like zinc has been found in different types of cancer. This study was conducted to see the serum level of zinc in breast cancer patients. Biopsy confirmed cancer breast, 50 female patients and 50 healthy female subjects were included in this study. Both control and study group patients were of same socio-economic status and dietary habits. Serum zinc level was estimated using standard absorption spectrometer technique. We observed significant low serum levels of zinc in carcinoma patients, as compared with normal healthy controls. This shows an association of serum zinc with cancer breast.
\end{abstract}

Keywords: Breast cancer, trace element, Serum Zinc, Atomic absorption spectrophotometer, biopsy

\section{Introduction}

Breast cancer is the second commonest form of cancer among women. In recent years, its prevalence is increasing in alarming pace ${ }^{1}$. Breast cancer found to be more common in developed countries and developing countries constitute $40 \%$ of all cases ${ }^{2}$. In India, breast cancer is the most common form of malignancy among women in urban area. In rural area, it is the second commonest form of cancer accounting for 25 to $32 \%{ }^{3} .53 \%$ of study people (Jharkand) had serum zinc deficiency and the deficiency was higher in females as compared to males ${ }^{4}$. Nutritional deficiency of zinc is wide spread in developing countries. ${ }^{5}$

Zinc is an essential trace element required by the human body for more than 300 cellular processes ${ }^{6}$ but can be toxic in excess and therefore requires a high level of regulation. Zinc importer (Zip) and transporter (ZnT) proteins facilitate cellular zinc homeostasis ${ }^{7}$ and several proteins within these families appear disturbed in breast cancer cells. Zinc which is essential for DNA polymerase activity, is particularly important in cell proliferation encountered in growing cell tumor. ${ }^{8}$ zinc is a trace element required for the growth of normal and neoplastic tissues in a variety of species zinc deficiency is associated with alterations in the activity of zinc dependent enzyme essential for cell replication. Dietary zinc deficiency also increases the incidence of certain tumors. ${ }^{9}$ Several studies have been conducted to identify potential risk factors. However, role of trace elements or metals in causing breast cancer has not been studied to great extent $^{10}$. Therefore, the present study was undertaken to estimate the serum levels of zinc and determine its role in causing breast cancer in female patients.

\section{Material \& Methods}

The study group consisted of 50 female patients of Breast carcinoma (mean age of $45.2 \pm 6.11$ year). The control group consisted 50 healthy subjects (mean age of $44.5 \pm 6.3$ year) Both study and control group were of same socio-economic status with similar diet habits. Patients were randomly selected irrespective to their caste and creed. Detailed history was taken to exclude any illness likely to effect the serum zinc level such as cirrhosis of liver, diabetes mellitus etc. such patients were discarded from the present study.

Blood samples were obtained by vein puncture and collected in a clean dry centrifuge tube. Standard precautions for trace element determination were taken, hemolysed samples were discarded. The blood was centrifuged at 3000rpm for 10 minutes and serum was stored at $-40^{\circ} \mathrm{C}$ until the day of the test, serum zinc concentration was determined by direct measurement method using atomic absorption spectroscopy.

Analytical reagent grade chemicals, standards were used. Water used for washing laboratory apparatus and for preparing solutions and standards was purified by deionization of redistilled water.

\section{Result}

The results as presented in the table 1 and fig. 1 show that the level of zinc was altered in subjects having breast cancer. A statistically significant decrease $(p<0.001)$ in serum zinc levels was observed in patients with breast cancer when compared to control.

Table 1: Comparison of Mean Serum Zn concentration (ug\%) in Breast Cancer Patients with that of control subject

\begin{tabular}{|c|c|c|c|}
\hline S.No. & Value & Beast Cancer Patients & Control Subjects \\
\hline 1. & Mean & 83.9 & 102.3 \\
\hline 2. & Range & $62.0-88.6$ & $85.0-130.0$ \\
\hline 3. & S.D. & 8.4 & 9.6 \\
\hline 4. & SE & 2.65 & 1.74 \\
\hline 5. & T & 8.95 & - \\
\hline 6. & p. value & $<0.001$ & - \\
\hline
\end{tabular}


International Journal of Science and Research (IJSR)

ISSN (Online): 2319-7064

Index Copernicus Value (2013): 6.14 | Impact Factor (2014): 5.611

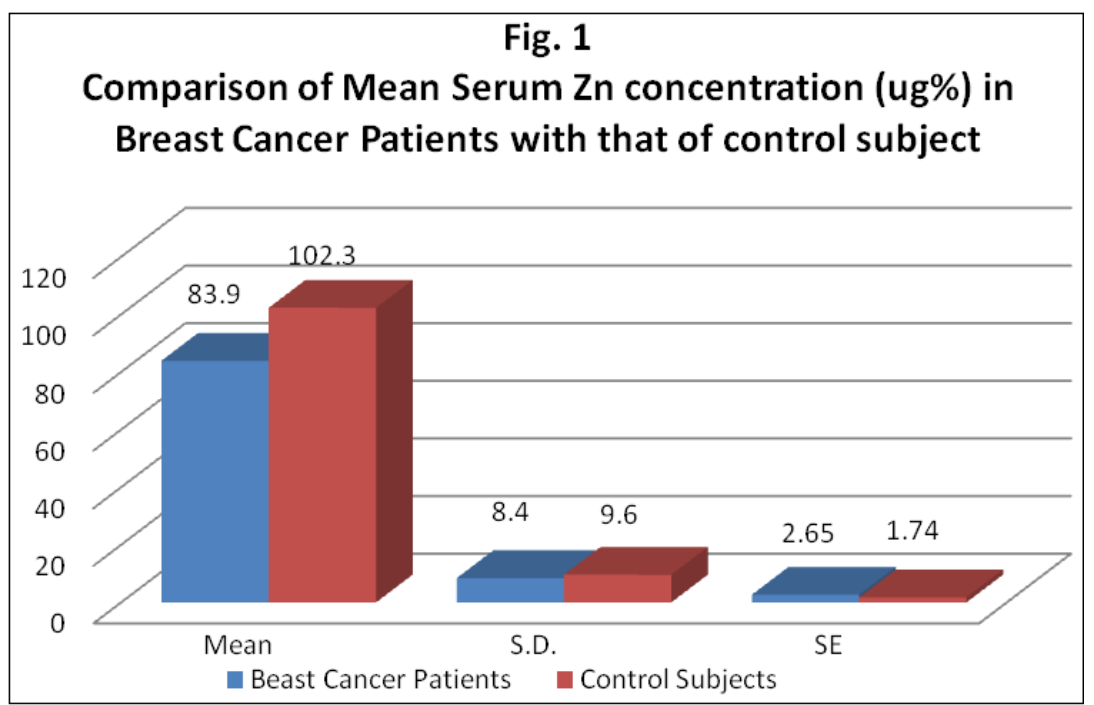

\section{Discussion \& Conclusion}

Trace elements and metals are known to play a vital role in metabolism. The mean serum zinc level was found to be decreased significantly in breast cancer patients as compared to that control group. Zinc act as an antioxidant, zinc is also vital for functions of many transcription factor and proteins that recognize certain DNA sequences and regulate gene transcription. Hence low levels of zinc is an important precondition for precancerous transformation. ${ }^{11}$ Zinc is important microelements which not only regulate the physiological functions of various organs but are also associated in the production of pathological changes in these organs. The association of serum trace elements and high cancer risk has been found in many studies. ${ }^{12,13}$ The result of present study of serum $\mathrm{Zn}$ level was similar to results obtained by previous studies which suggested that serum $\mathrm{Zn}$ level in breast carcinoma patients decreases significantly as reported by Davies et al(1968), ${ }^{14}$ Tinoco-Veras et al $(2011)^{15}$, Alam et al (2012), ${ }^{16}$ Pavithra et al (2015). ${ }^{17}$

Although, the mechanism underlying the deviation of serum zinc in malignancy is not clear but however the decrease in serum zinc level might be due to stress induced by the malignancy. Davies et al $(1968)^{14}$ reported that many factors including various diseases and stress induce the lowering of serum zinc concentration.

Our data does not allow us to conclude whether low $\mathrm{Zn}$ level occurred as a results of the cancer However the result of present study indicate the role of zinc as compounding factor in the development of breast cancer. The individuals with abnormal serum levels can be subjected to further investigation to identify precancerous changes or early malignant changes. Further studies are required to establish the role of estimation of serum metal ions in this regard.

\section{References}

[1] Parkin DM., Bray F, Ferlay J, Pisani P. Global cancer statistics 2002. Cancer J Clin. 2005;55:74-108.

[2] Sharma BK, Ray A. Breast and prostate cancer. IJCB. 2001;15:110-17.
[3] Pink Indian statistics, Breast. Cancer. India. Trends of breast cancer in India, [Internet], http://www.breastcancerindia.net/bc/statistics/stati.html. [accessed on 20/4/14, 15:34].

[4] Kapil, Umesh .et al. Serum zinc levels amongst tribal population in a district of Jharkhand state (India): A Pilot study. Eastern Journal of Medicine .2003; 8 (2): 33-34.

[5] 5 . Prasad AS.Zinc and immunity. Mol.Cell.Biochem.1998;188:63-69.

[6] Kelleher SL, McCormick NH, Velasquez V and Lopez $\mathrm{V}$. Zinc in specialized secretory tissues: roles in the pancreas, prostate and mammary gland. Adv. Nutr. 2011; 2: 101-111.

[7] Chasapis CT, Luotsidou AC, Spiliopoulou CA and Stefanidou ME. Zinc and human health: an update. Arch. Toxicol. 2012; 86:521-534.

[8] Aggett PJ and Harris JT. Current status of zinc in health and disease states. Arch.Dis.Child.1979;54:909.

[9] Barch DH and Iannaccone PM. Role of zinc deficiency incarcinogenesis.Adv.Exp.Med.Biol.1986;206:517-527.

[10] Adebamowo CA, Hu FB, Cho E.et al. Dietary patterns and the risk of breast cancer. Ann Epidemiol. 2005;15(10):789-95.

[11] Magalora T, Bella V, Brtkova A, Beno I, Kudlackova M, and Volkovova K. Copper, zinc, super oxide dismutase in precancerous, benign disease and gastric, colourectal and breast cancer. Neoplasma. 1999;46:100-04.

[12] Mark SD, Qiao L, Dawsey SM. et al. Prospective study of serum selenium levels and incident esophageal and gastric cancers. J. Natl. Cancer Inst.2000; 92 (21): 1753-1763.

[13] Tandon M. et al. Role of micronutrients and trace elements in carcinoma of larynx. The Journal of the Association of Physicians of India. 2000; 48: 995-8.

[14] Davies IJT, Musa M and Dormandy TL .Measurements of plasma zinc part II. In malignant diseases. J.Clin.Path. 1968;21:359.

[15] Tinoco-Veras CM, Bezerra Sousa MS. et al. Analysis of plasma and erythrocyte zinc levels in premenopausal women with breast cancer. Nutr. Hosp. 2011; 26: 293297.

[16] Alam S and Kelleher SL. Cellular mechanisms of zinc dysregulation: A perspective on zinc homeostasis as an

\section{Volume 4 Issue 11, November 2015}




\section{International Journal of Science and Research (IJSR) \\ ISSN (Online): 2319-7064}

Index Copernicus Value (2013): 6.14 | Impact Factor (2014): 5.611

etiological factor in the development and progression of breast cancer.Nutrients.2012; 4: 875-903.

[17] Pavithra V, Sathisha TG.et al. Serum Levels of Metal Ions in Female Patients with Breast Cancer, Journal of Clinical and Diagnostic Research. 2015 Jan; Vol-9(1): BC25-BC27.

\section{Author Profile}

Kim Chawla is a Sr. demonstrator, Department of Biochemistry in S.P. Medical College Bikaner (Rajasthan). India. 